\title{
Financial dollarization and systemic risks: new empirical evidence
}

\author{
Encontro Nacional de Economia - ANPEC 2012 \\ Área 3 - Macroeconomia, Economia Monetária e Finanças \\ Fabrício de Assis C. Vieira \\ PUC Minas \\ fabricioacvieira@yahoo.com.br \\ Márcio Holland \\ EESP-FGV \\ marcio.holland@fgv.br \\ Marco Flávio da Cunha Resende \\ CEDEPLAR-UFMG \\ resende@cedeplar.ufmg.br
}

\begin{abstract}
:
This paper explores the persistence of financial dollarization in a group of 79 economies with different levels of development. Our main hypothesis is that a high level of domestic debt combined with default risk explains this persistence, even after a decline in inflation rates. Using the generalized method of moments (GMM) in a panel data analysis, our results show that inflation risks caused by increasing probability of default account for financial dollarization more than inflation rate itself. After the decrease in inflation rates, the foreign currency-denominated deposits remain large because of the high debt-to-GDP ratios, particularly in speculative-grade economies. High public indebtedness leads to expectations of default. Dollarization is a rational response to the future inflation associated with investors' expectations of default observed in highly indebted economies.
\end{abstract}

Keywords: Financial Dollarization; Risk of Inflation; Risk of Default JEL Classification: E50; G11; G20

\section{Resumo:}

Este trabalho verifica a persistência da dolarização financeira para um grupo de 79 economias com diferentes níveis de desenvolvimento. A hipótese principal é que altos níveis de endividamento doméstico combinado com riscos de calote de dívida explicam esta persistência, mesmo após a queda nas taxas de inflação observadas nestas economias. Usando o Método dos Momentos Generalizados (GMM) em uma análise de dados em painel dinâmico, nossos resultados mostram que os riscos de inflação causados pelo aumento da probabilidade de calote explicam mais a dolarização financeira do que a taxa de inflação por si só. Após a queda nas taxas de inflação, os depósitos em moeda estrangeira permanecem altos devido à alta razão dívida-PIB, especialmente em economias com grau especulativo. Elevado endividamento público conduz a expectativas de calote, de modo que a dolarização financeira é uma resposta racional para a inflação futura, associada com as expectativas dos investidores de calote de dívida pública observada em economias altamente endividadas.

Palavras-chave: dolarização financeira; risco de inflação; risco de calote Classificação JEL: E50; G11; G20 


\section{Introduction}

Since the early 2000s, a growing number of countries have fully or partially adopted foreign currencies, such as the European Monetary Union (EMU) euro or the United States (US) dollar, or have maintained a large portion of their bank deposits in another country's currency. Europe provides the clearest example because countries within the region abandoned their domestic currencies to become members of the EMU. Nearly 60 small countries or territories are former or current members of some type of monetary union or use a large country's currency. In Africa, 14 countries are members of the African Financial Community. The Eastern Caribbean Currency Union has eight member countries, including Dominica, Grenada and Santa Lucia, and uses a single currency, the Eastern Caribbean dollar. Some countries, such as Panama, Ecuador and El Salvador have adopted the US dollar as their official currency. Other countries, including Argentina and China Hong Kong, have embraced strict currency-board-based monetary regimes without abandoning their own currencies. Furthermore, some countries (e.g., Bolivia and Uruguay) have more than 65 percent of their bank deposits in a foreign currency such as the US Dollar, the Euro or another strong currency.

The dollarization of an economy is always strongly associated with inflation. All of the previous studies confirm this relationship. Furthermore, studies have been performed concerning dollarization remaining relatively high even after inflation rates have dropped. In this case, inflation and the risk of inflation explain dollarization. Many countries that witnessed declines in their inflation rates to low levels maintained high demand for US dollar deposits or US dollar-denominated assets or liabilities, both domestically and internationally, because of the risk that inflation might return.

Two other factors are found in the literature. First, despite the belief in persistent dollarization, empirical tests fail to support this phenomenon. Second, several economies remain risky because they display a high default risk in addition to inflation concerns. For this study, the determinants of financial dollarization for 79 developed and developing economies were examined to assess how relevant the risk of default is to the risk of inflation. The core hypothesis is that high indebtedness combined with systemic risks, including inflation volatility and the risk of default on debt, explains the persistence of financial dollarization in the affected economies, even after inflation decreases. In addition, the paper controls for persistent dollarization in a dynamic-panel data model. Our results show that dollarization persists and remains high despite a reduction in the inflation levels because growing levels of domestic public indebtedness increases the risk of sovereign default, especially in non-investment grade economies. Highly public indebtedness generates investor's expectations of a government default, which leads to future inflation expectation even in a low-inflation environment.

Then, after the decrease in inflation rates, the foreign currency-denominated deposits remain large because of the high debt-to-GDP ratios, particularly in speculative-grade economies. High public indebtedness leads to expectations of default. Dollarization is a rational response to the future inflation associated with investors' expectations of default observed in highly indebted economies. According to our results dollarization is a rational response to the default risk, specially in speculative grade countries. Therefore, because history of default is close associated with history of inflation (Reinhart, Rogoff, and Savastano, 2003), capital flight leads to a currency depreciation and lead also to inflation through exchange rate pass-through. However, this second part is only a plausible story in which we have no empirical findings.

The paper is structured as follows. Section 2 reviews the theory of financial dollarization, describing the causes and consequences of dollarization according to the 
four primary viewpoints. Section 3 analyzes the relationship between dollarization, inflation risks and debt, and shows that drops in inflation are not followed by reduced financial dollarization, and that high levels of dollarization are associated with high indebtedness levels. Section 4 examines the relationship between dollarization and the risk of default, and introduces new measures to explain dollarization and its persistence over time, such as domestic public debt and the country's investment grade. Section 5 contains an empirical analysis of the determinants of dollarization and utilizes the new variables from Section 4. Using estimations of dollarization determinants with dynamic models, we show that our lagged dependent variable and lagged explanatory variables explain financial dollarization. Section 6 provides the concluding comments.

\section{Literature Overview}

Several approaches have been proposed to explain the causes of financial dollarization. There are four primary views in the literature: the monetary substitution view, the asset portfolio view, the institutional view, and the market failure view. Calvo and Rodrigues (1977), Liviatan (1981) and Miles (1978) provide the earliest models dealing with dollarization in terms of monetary substitution. These models assume the presence of two kinds of assets (domestic currency and foreign currency), whereas the asset portfolio models originating from Miles (1978), Thomas (1985) and Branson and Henderson (1985) additionally assume the presence of domestic-currency- and foreigncurrency-denominated securities. All of these models credit high inflation levels as the cause of dollarization and monetary substitution. The domestic currency's loss of value leads to its substitution by a strong foreign currency (e.g., the US dollar). Empirically, the level of inflation is positively correlated with dollarization, as shown in Yeyati (2006), De Nicoló et al. (2005), Bacha et al. (2009) and Kokenyne et al. (2010).

Institutional factors also played an important role in several economic ouctomes. In a seminal contribution, North and Weingast (1989) show how checks on executive discretion increase the government's commitment to property rights. On the other hand, Acemoglu et al. (2001) show that different institutions led to different property rights levels, which, in their turn, affect the economies' economic development and per capita GDP. In the dollarization process, as noted by Savastano (1992) and Yeyati (2006), the quality of institutions may influence the variables leading to dollarization. Weak institutions detract from the credibility of a commitment not to bail out dollar debtors in the event of a sudden devaluation, and may compound the mispricing associated with implicit government guarantees. Furthermore, weak institutions may undermine the credibility of domestic policies, as residents fear that their governments will erode the value of financial assets by generating unexpected future inflation. Lastly, weak institutions may also raise doubts about contract enforcement. The main proponents of this view are De Nicoló et al. (2003), De La Torre et al. (2003) and Honig (2009).

The variables used in the works by Yeyati (2006), Rennhack and Nozaki (2006) and Yeyati and Sturzenegger (2005) include an index for restrictions against the holding of foreign currency deposits by residents, the initial per capita income, an index for the rule of law, and a foreign exchange dummy variable as measures of national institutional quality. Their results indicate negative relationships between the level of dollarization and restrictions on dollarization, initial per capita income and rule of law. The rule of law variable, sourced from the World Bank's World Wide Government Indicators (WGI), was also used by Arida et al. (2005) and Bacha et al. $(2007,2009)$ as a proxy for jurisdictional uncertainty, a concept proposed by Arida et al. (2005). This variable attempts to capture the governmental uncertainties that financial investors face 
in countries where institutions are weak. The results of Bacha et al. (2009) show that an increase in jurisdictional uncertainty leads to an increase in financial dollarization. The authors also used other variables from the WGI, to indicate institutional quality, but their results were unsatisfactory despite strong correlations ${ }^{1}$.

Honig (2009) argues that financial dollarization results from the belief that the government will not adopt policies promoting the currency's long-term stability, even if the current economic policy has successfully controlled inflation and limited foreign exchange rate oscillation. The fear that the policy may change in the future leads to dollarization even in low-inflation environments. In an empirical study, Honig (2009) uses the following variables to measure government quality: quality of the bureaucracy, government corruption, law and order, and term of central banks governors. The author empirically observes that government quality is an important variable in explaining financial dollarization, since quality governments increases institutional power to prevent the adoption of policies leading to loss of monetary stability.

In the same vein, Weymouth (2011) argues that institutional checks on policymaker discretion (Veto Players) improve the property rights of investors regarding the value of the domestic currency. According to the author, Veto Players restrict policymakers' ability to adopt policies leading to depreciation of the domestic currency or to inflation, improving the property rights of domestic currencydenominated asset holders ${ }^{2}$. Therefore, financial dollarization is a result of investors' low confidence in their property rights, which, in turn, occurs when a small number of Veto Players exist in a society. Weymouth (2011) uses a 127-country to show that the larger the number of Veto Players, the lower the level of financial dollarization.

Concerning the foreign-exchange regime and how it relates to the level of dollarization, the literature shows contradictory results in addition to endogeneity problems and issues arising from causality between the two variables. Yeyati and Sturzenegger (2005) show empirically that countries with fixed-exchange regimes tend to have larger dollarized deposits. Arteta (2003) and Weymouth (2011) report that dollarized deposits are larger under more flexible foreign-exchange regimes, which may indicate that less flexible regimes have a monetary commitment mechanism that reduces hedging in the form of foreign currency deposits.

The market failure view attempts to explain the bias toward dollarization by relating it to market imperfections and externalities. Broda and Yeyati (2006) argue that this bias arises from the combination of positive correlations between the probability of default, the real rate of exchange and imperfect information about the monetary makeup of the obligors. The main proponents of this view are De La Torre and Schmukler (2004) and Jeanne (2000). Using the correlation between real gross domestic product (GDP) changes and real exchange rate changes as proxies for the correlation between the probability of default and the real rate of exchange, Yeyati (2006) shows that dollarization increases with a country's probability of default.

The portfolio view of dollarization stems from a financial dollarization model developed by Ize and Yeyati (2003) based on the contributions of Miles (1978) and Girton and Roper (1981). Unlike these authors, Ize and Yeyati determined the portfolio composition on both sides of the banking balance sheet by hedging against inflation and against the risk of foreign change. Therefore, deposits and loan dollarization interact

\footnotetext{
${ }^{1}$ In addition, other institutional quality variables obtained from the World Bank's WGI database include political stability, regulatory quality and control of corruption.

${ }^{2}$ Veto Players restrict opportunistic policies because it requires an agreement among various political agents representing different interests. Also according to the theory of veto players, policy outcomes must lie within a range that satisfies all players, Weymouth (2011).
} 
through the tradable funds market, and this interaction leads to a financial equilibrium that revolves around interest rate parity and minimum variance portfolio (MVP) allocations. As a result, the MVP, which is a function of the foreign exchange rate volatility and inflation volatility, provides an approach to measuring financial dollarization and its relationship with economic stability. In the portfolio approach, according to Ize and Yeyati $(2003)^{3}$, risk-averse local creditors choose between US dollar-denominated and peso-denominated (domestic currency) assets. The interest rates on these assets are:

$$
\begin{aligned}
& r_{d}=E\left(r_{d}\right)+\mu_{s} \\
& r_{p}=E\left(r_{p}\right)-\mu_{\pi}
\end{aligned}
$$

where $\mu_{s}$ and $\mu_{\pi}$ are the mean deviations from the real foreign exchange rate depreciation and inflation rate. The creditors' problem lies in maximizing the utility function:

$$
\max _{x j} \mathrm{U}=E(r)-c_{L} \operatorname{Var}(r) / 2
$$

where $\mathrm{x}_{j} \geq 0, j=p, d$ are the shares of peso-denominated and US dollar-denominated assets, and $r=\sum_{j} x_{j} r_{j}$ e $c_{L}>0$ reflects the creditors' aversion to risk.

Assuming that the hypothesis of uncovered interest rate parity is valid, the share of US dollar-denominated assets in the investment portfolio replicates the MVP:

$$
m v p=(\operatorname{var}(\pi)+\operatorname{cov}(\pi, s)) /(\operatorname{var}(\pi)+\operatorname{var}(s)+2 \operatorname{cov}(\pi, s))
$$

Therefore, at the MVP equilibrium, dollarization is better explained by the second moments of inflation and real depreciation than by the first moments as in monetary substitution models. In the above equation, $\operatorname{var}(\pi)$ represents the variance in inflation, whereas $\operatorname{cov}(\pi, s)$ is the covariance between inflation and real exchange rate changes. In this model, if the inflation volatility remains high compared with the exchange rate volatility, hysteresis may occur even as memories of past economic disequilibria fade. The empirical results from Ize and Yeyati (2003) support this hypothesis. Using past information on inflation volatility and exchange rate volatility, these authors calculated the share of US dollar-denominated assets in the MVP, and verified that this share approaches the current dollarization for a sample of five of the most dollarized economies in Latin America. Rennhack and Nozaki (2006), De Nicoló et al. (2005), Yeyati (2006) and Honohan (2008) also have identified a positive relationship between the share of US dollars in the MVP and the level of dollarization.

\section{Dollarization, Inflation Risks and Public Debt}

This section provides a preliminary empirical analysis of dollarization, inflation risks and debt in developed and developing countries. We used a sample of 79 countries from five continents - Africa, North America (except the United States), South and Central America (America, for short), Asia and Europe - over the periods 1991-98 and $1999-06^{4}$. The selections of the countries and time spans were due to the availability of data on the dollarized deposit variable and other variables. A significant portion of assets and liabilities held by a country's residents are in foreign currency in many developing countries with histories of high inflation, such as Argentina, Bolivia and Peru. However, many economies continue to maintain a large portion of their domestic

\footnotetext{
3 Ize and Yeyati's (2003), Thomas's (1985) and Miles's (1978) portfolio choice models were based on Markowitz's (1952) portfolio selection model.

${ }^{4}$ Table A. 1 in the appendices lists the 79 countries used in this study.
} 
bank deposits in foreign currency (financial dollarization), mainly in the US Dollar, even after the high inflation period has ended.

Remarkably, dollarization increased in the 79-country group even after inflation dropped (Table 1). Despite keeping inflation under control since 1999, the level of dollarization increased, reaching an average of $29.5 \%$ in America. Countries such as Uruguay and Bolivia remain highly dollarized, with over $80 \%$ (on average) of their assets in foreign currency deposits, although inflation has decreased since 1997.

As shown in Table A.3 (Appendix), thirteen countries from our sample show dollarization increases in excess of 1.6 percentage point (p.p.) in years of decreasing inflation. Furthermore, 50 of the 79 economies show dollarization increases of 1 p.p. or more in years when inflation dropped by at least 1 p.p. Where inflation levels appeared to not be strongly correlated with the level of dollarization, we assessed the role of inflation volatility as measured by the variance of inflation. Inflation volatility in the periods 1991-98 and 1999-06 (Table A.4) shows a very small decrease in all four regions, whereas dollarized deposits grew in excess of 3 p.p. in all of them, with a 10.5 p.p. increase in overall dollarization and an average of $30 \%$ of dollarized deposits. Table A.4 also shows that the share of dollar in the Minimum Variance Portfolio (MVP) also decreases in all four regions in the periods 1991-98 and 1999-06. Furthermore, given that inflation volatility is used in calculating MVP, we find that American countries had the smallest drops in both inflation volatility and the MVP variable, whereas Asian countries had the smallest drops in MVP and inflation volatility.

Measuring the inflation acceleration by the variation of the inflation rates for the two periods, we see that inflation declined for the selected countries in America, Africa, Europe and Asia. Therefore, inflation rates decreased in all of the continents, whereas dollarized deposits increased in all of them.

Table 1

Average Inflation, Dollarization and Debt/GDP by period and region

\begin{tabular}{|c|c|c|c|c|c|c|}
\hline $\begin{array}{c}\text { Region and } \\
\# \text { of } \\
\text { countries }\end{array}$ & $\begin{array}{c}\text { Dollarized } \\
\text { deposits 1991-98 } \\
(\%)\end{array}$ & $\begin{array}{c}\text { Inflation } \\
1991-98 \\
(\%)\end{array}$ & $\begin{array}{c}\text { Debt /GDP } \\
1991-98 \\
(\%)\end{array}$ & $\begin{array}{c}\text { Dollarized } \\
\text { deposits 1999-06 } \\
(\%)\end{array}$ & $\begin{array}{c}\text { Inflation } \\
1999-06 \\
(\%)\end{array}$ & $\begin{array}{c}\text { Debt /GDP } \\
\text { 1999-06 } \\
(\%)\end{array}$ \\
\hline $\begin{array}{c}\text { Latin, } \\
\text { North, } \\
\text { South and } \\
\text { Central } \\
\text { America } \\
(22)\end{array}$ & 27.6 & 15.9 & 54.5 & 30.7 & 5.9 & 55.6 \\
\hline Africa (4) & 32.8 & 13.4 & 71.4 & 36.2 & 4.2 & 68.6 \\
\hline Asia (25) & 22.1 & 7.9 & 56.1 & 27.2 & 3.8 & 60.8 \\
\hline Europe (28) & 23.4 & 15.7 & 50.1 & 26.7 & 6.5 & 45.9 \\
\hline
\end{tabular}

What could be the cause of increased financial dollarization of these economies 
despite the lower levels of inflation? The answer may be related to the level of public indebtedness, which implies in future high inflation. Public indebtedness levels, measured by domestic public debt to GDP, increased in countries in America and Asia, reduced indebtedness in Europe and African countries in 1999-2006 from 1991-98.

Asian countries exhibited the greatest reductions in inflation volatility, inflation acceleration, MVP, and the largest increase in dollarized deposits. Although the decline in inflation acceleration exceeded 3 p.p. in Asia, Africa had the smallest decline in inflation acceleration and the second highest increase in dollarized deposits. European countries showed the largest reduction in the debt-to-GDP ratio, whereas Asia exhibited the largest increase in this variable, up to $60.8 \%$ from $56.1 \%$ (Tables 1 and A.4). Africa and America have the highest dollarization levels, whereas Europe has the lowest level. Our hypothesis that dollarization persists because of a combination of indebtedness and the risks of sovereign default and future price dilution appears plausible.

That is, even at low current inflation rates, risks of future inflation may arise in highly indebted economies. The fact that the increase in financial dollarization does not come hand in hand with an increased share of the US Dollar in MVP suggests that the inflation volatility present in the construction of the variable MVP is only capturing current inflation risks, and not future ones. Future inflation risks are being captured by the combination of high public indebtedness and default risks, particularly in speculative-grade economies.

\section{Dollarization and the Risk of Default}

Considering that dollarization persists even after a decline in inflation in the studied economies, our hypothesis is that this persistence can be explained by the high levels of public debt and sovereign risks. Government spending and revenues may be covered through raising taxes, issuing money or borrowing through public bonds. The issuance of currency (i.e., the monetisation of debt) and seigniorage may cause inflation to reach uncontrollable levels, as shown by Cagan (1956), Friedman (1963) and Sargent (1982). This practice has been common in economies around the world, especially those that endured wars or declining export prices and taxes. These circumstances create a need to fund public deficits through money issuance, given the low reliance of investors on their bonds (Romer, 2006). Besides this, many Latin American countries resorted to massive monetary issuances to cover spending during markets with low domestic bond demand, which prevented spending from being financed via debt issues and domestic debt expansion. However, several studies show that the decreased in inflation in the nineties was followed by decreased in seigniorage in emergent and advanced economies around the world. Hawkins e Masson (2003) e Hawkins (2003) have showed that seigniorage decreased in the nineties from eighties in countries such as China, Filipinas, Brazil, Mexico and United Kingdom. Besides this, the decreased in inflation levels have contributed to the development of domestic financial markets as noted by De Nicoló et al. (2003). These authors have showed that a 1 p.p. increase in inflation level causes an average decrease of 0.5 p.p. in the financial depth of economies. This financial depth have contributed to the increased of issuing bonds by the government in the nineties.

Concerning the government funding via bond issues, the resulting generation of public debt does not appear to cause price increases. However, if investors (local and foreign) expect the local government to default on its debt and fail to repay the issued securities, then the investors will tend to flee. The investors will sell their local assets, generating a flight of US dollars and devaluing the exchange rate. This action leads to inflation and discourages the purchase of assets in the local currency. Rational investors 
will tend to sell their peso assets (denominated in domestic currency) before the government default, which may happen or not.

Thus, according to our hypothesis, the issuance of public bonds to fund increasing government spending may generate expectations of price increases in the economy, raising the risk investors face when purchasing assets based on the local currency (future inflation risk). If local and foreign investors realize that the government's bonds carry risk and that the government may fail to honor its bonds, the investors will lack the incentives to invest in the local assets, even if the current levels of inflation are low. Therefore, government bonds must be perceived as credit risk-free even under low inflation conditions, so reducing the debt-to-GDP ratio and fiscal consolidation are essential to the creation of a reliable legal and institutional environment for investors.

Another important variable in explaining persistent dollarization is the measure of sovereign risk, which indicates the country's investment grade, reflecting the risk perception that international agencies use to rate sovereign states. In a study of the role of dollarization and systemic risk in the determination of the real interest rate of a group of countries, Bacha et al. (2009) used this variable as a proxy for the risk of sovereign default along with the national per capita income ${ }^{5}$. Economies that have not yet attained investment-grade status pose higher risks of sovereign default than those that have, and investment-grade status tends to improve the rates and terms that can be obtained in the global financial market. International agencies and investors regard an investment-grade economy as a safe investment that would honor its financial obligations, encouraging the purchase of domestic assets in local currency and reducing dollarization.

The capital account openness level is also an important explanatory variable for financial dollarization. More financially open economies with fewer capital controls tend to have more dollarized deposits because of their increased ability to both take and grant loans abroad, increasing the purchase of foreign currency assets by domestic investors. In addition, greater capital mobility increases the sensitivity of domestic residents' portfolio reallocations to foreign exchange rates (Arteta, 2002). Although important in explaining dollarization, the variable that reports capital account openness levels is seldom used in the literature and is sometimes replaced by the trade openness variable, as in De Nicoló et al. (2005). The trade openness variable does not represent capital account openness. The capital account openness level is frequently used in studies on real interest rates and dollarization, as in Arida et al. (2005), Gonçalves et al. (2007), Salles (2007), and Bacha et al. (2009). Along with the index for restrictions against dollarization and the rule of law according to the World Bank's governance indicators, the capital account openness index serves to capture the attitudes of governments toward dispensing foreign funds. The results of Bacha et al. (2009) show that economies with fewer capital controls are more dollarized. However, the capital account openness level lacks direct explanatory power for the real rate of interest, a finding similar to those of Gonçalves et al. (2007) and Salles (2007).

\section{Econometric Analysis using System GMM}

The purpose of this section is to verify the determinants of financial dollarization and its persistence over time for a group of 79 countries from four different regions: America, Africa, Asia and Europe. The relevant period is 1996-2006, which is the period for which we have information about dollarized deposits, restrictions to dollarization, inflation, inflation volatility, inflation acceleration, MVP, initial per capita

\footnotetext{
${ }^{5}$ Bacha et al. (2009) used Standard \& Poor's to rate countries as investment-grade or not. This rating is similar to Moody's, used here, with only a few differences in terms of country coverage and period.
} 
income, foreign-exchange regime classification, financial openness index, rule of law (and other institutional variables), debt/GDP, and sovereign risk rating.

\subsection{Empirical Econometric Model}

The dynamic relationship for the financial dollarization equation is characterized by the presence of a lagged dependent variable between the regressors as follows:

$$
y_{i t}=\delta y_{i, t-1}+X_{i t}^{\prime} \beta+u_{i t}, \quad \text { with } \mathrm{i}=1, \ldots, \mathrm{N} \text { and } \mathrm{t}=1, \ldots, \mathrm{T}
$$

where $\delta$ is a scalar; $X_{i t}^{\prime}$ is the $1 \mathrm{x}$ k vector of explanatory variables, which may be strictly exogenous, endogenous or predetermined; and $\beta$ is the $\mathrm{k} \times 1$ vector of coefficients. Assume that $u_{i t}$ follows the error component model below:

$$
u_{i t}=\mu_{i}+v_{i t}
$$

where $\mu_{i} \sim \operatorname{IID}\left(0, \sigma_{\mu}^{2}\right)$ and $v_{i t} \sim \operatorname{IID}\left(0, \sigma_{v}^{2}\right)$.

Component $\mu_{i}$ represents individual (country-specific) fixed effects that do not vary over time, and $v_{i t}$ represents country-specific shocks and varies over time. The latter shocks are heteroskedastic and are correlated over time within individuals but not among them. We assume therefore that:

$$
\begin{aligned}
& E\left(\mu_{i}\right)=E\left(v_{i t}\right)=E\left(\mu_{i} \cdot v_{i t}\right)=0 \\
& E\left(v_{i t} \cdot v_{j s}\right)=0 \text { for each } \mathrm{i}, \mathrm{j}, \mathrm{t}, \mathrm{s}, \text { with } i \neq j
\end{aligned}
$$

The strictly exogenous variables do not depend on the current or past errors $v_{i t}$, whereas the predetermined ones (including the lagged dependent variable) are potentially correlated with the past errors $v_{i t}$ and may be correlated with the individual fixed effects $\mu_{i}$. The endogenous variables are potentially correlated with the past and current errors $v_{i t}$ and may be correlated with the individual fixed effects $\mu_{i}$.

The panel model estimations in (5) and (6) are characterized by two sources of persistence over time. Autocorrelation due to the presence of a lagged dependent variable among the regressors and individual effects characterizing the heterogeneity among the individuals. The inclusion of the lagged dependent variable as one of the explanatory variables in (5) makes the OLS estimator $\delta$ biased and inconsistent even if the error term $v_{i t}$ is not serially correlated ${ }^{6}$. To overcome this problem, let's try to use the fixed effects estimator. Taking the time average of the variables in (5):

$$
\bar{y}_{i}=\delta \bar{y}_{i}+\bar{x}_{i} \beta+\bar{\mu}_{i}+\bar{v}_{i}
$$

Subtracting equation (8) from (5) we have:

\footnotetext{
${ }^{6}$ Because $y_{i, t}$ is a function of $\mu_{i}, y_{i, t-1}$ is also a function of $\mu_{i}$. Therefore, $y_{i, t-1}$, the regressor on the right side of Equation (5), is correlated with the error term.
} 


$$
\begin{aligned}
& \left(y_{i t}-\bar{y}_{i}\right)=\left(y_{i, t-1}-\bar{y}_{i}\right) \delta+\left(x_{i t}-\bar{x}_{i}\right) \beta+\left(\mu_{i}-\mu_{i}\right)+\left(v_{i t}-\bar{v}_{i}\right) \\
& \left(y_{i t}-\bar{y}_{i}\right)=\left(y_{i, t-1}-\bar{y}_{i}\right) \delta+\left(x_{i t}-\bar{x}_{i}\right) \beta+\left(v_{i t}-\bar{v}_{i}\right)
\end{aligned}
$$

This transformation wipes out the $\mu_{i}$ (individual fixed effects), but $\left(y_{i, t-1}-\overline{y_{i}}\right)$ will still be correlated with $v_{i t}-\bar{v}_{i}$ even if the $v_{i t}$ are not serially correlated. This is because $y_{i, t-1}$ is correlated with $v_{i t}$ by construction. Baltagi (2005) also shows that in dynamical panel models the Random Effects Estimator is biased. An alternative transformation that wipes out the individual effects is the first difference transformation, as suggested by Anderson e Hsiao (1981). To obtain consistent estimates for the $\delta$ parameters and the $\beta^{\prime}$ s, we use the first difference of Equation (5) to eliminate the individual effects and thereby remove the source of inconsistency in the model:

$$
\begin{aligned}
& \left(y_{i t}-y_{i t-1}\right)=\delta\left(y_{i t-1}-y_{i t-2}\right)+\beta\left(X_{i t}-X_{i t-1}\right)+\left(\mu_{i}-\mu_{i}\right)+\left(v_{i t}-v_{i t-1}\right) \\
& \Delta y_{i t}=\delta\left(\Delta y_{i t-1}\right)+\left(\Delta x_{i t}^{\prime}\right) \beta+\left(\Delta v_{i t}\right)
\end{aligned}
$$

This differentiation procedure eliminates the individual fixed effects and makes the predetermined variables into endogenous. As a result, a predetermined variable present in $\left(X_{i t}-X_{i t-1}\right)$ may be correlated with the errors $v_{i, t-1}$ in $\left(v_{i, t}-v_{i, t-1}\right)$. The estimator from the GMM in Arellano and Bond (1991) solves the problem by instrumentalizing the differenced variables $\left(\Delta x_{i t}^{\prime}\right)$ that are not strictly exogenous with their available lags in level. However, using this first-difference estimator (difference $G M M$ ), the available lags in level may be weak instruments for the variables that are not strictly exogenous if the relevant lags are roughly a random walk. To overcome this problem, Arellano and Bover (1995) and Blundell and Bond (1998) suggest adding the original equation (5) in levels to the GMM criterion, increasing the efficiency by including additional instruments. Therefore, we have a two-equation system known as the system GMM in which the differenced variables in the difference equation are instrumentalized with their available lags in level. In the level equation, the variables are instrumentalized with suitable lags of their own first-differences. The instrumentalized variables' differences are uncorrelated with the fixed effects.

\subsection{Results of the Dynamic Panel Estimations}

Because our goal was to check whether the causes of persistent dollarization are connected with the various types of risk (i.e., inflation risks and default risks) present in a broad sample of countries, the variables included in the estimations were the inflation volatility, inflation acceleration, inflation, MVP, rule of law, internal public debt-toGDP, investment/speculative grade ${ }^{7}$ and an interaction variable between debt-to-GDP and speculative grade. As a benchmark model, we initially estimated a specification that included all of the explanatory variables described earlier, using Two Step System GMM. We use dynamic panel models because our dependent variable is quite persistent

\footnotetext{
7 The dummy for speculative grade assumes value 1 for non-investment grade countries and 0 for countries that have already attained investment-grade status.
} 
over time, as discussed in previous sections. Even with the decrease in the inflationary variables, the degree of deposit dollarization is still high, especially in economies with higher debt-to-GDP ratios and higher sovereign risks.

The System GMM estimations were made using current and one-period-lagged variables along with the one-period-lagged dependent variable, to capture the persistence of dollarization ${ }^{8}$. Among others, Arellano and Bond (1991) and Blundell and Bond (1998) also have included the lagged explanatory variables in dynamical panel models. In our estimations (Table 2), the one-period-lagged dependent variable was statistically significant at $1 \%$ with a coefficient of 1.09 . This lag likely captures the strong persistence of dollarization. The other statistically significant variables in the Model 1 were current inflation, one-period-lagged MVP, current rule of law, oneperiod-lagged rule of law, speculative Grade, and initial per capita income. Concerning the variables associated with inflation, our results show a positive relationship between financial dollarization and those variables. The MVP variable is calculated using past information's on inflation volatility and exchange rate volatility ${ }^{9}$. The lagged MVP variable was statistically significant at $5 \%$, with a coefficient of 0.26 . The coefficient associated with the current inflation variable was 0.37 , albeit statistically significant at $10 \%$. These results indicate that higher levels of inflation and higher inflation volatility lead to reallocations in portfolio's agents. Such agents will tend to sell domestic assets and buy assets denominated in foreign currency (especially the US dollar).

The fact that the lagged coefficient of the MVP variable is statistically significant while its present value is not appears to confirm the temporal persistence of our dependent variable. Our group of countries shows, as do other studies, that the share of the US Dollar in the minimum variance portfolio (MVP) in period $t$ is quite close to dollarized deposits in the same period $t$. Therefore, given that dollarized deposits are persistent over time, the share of the US Dollar in actors' portfolios in period $t-1$ will also be close to dollarized deposits in period $t$.

The coefficients associated with the institutional variable rule of law were statistically significant at 5\% and show an interesting result. The current coefficient has a positive value of 1.61 , although its lagged value was approximately -1.73 . The rule of law variable measures the extent to which agents have confidence in and abide by the rules of society, including the quality of contract enforcement and property rights, the police, and the courts, as well as the likelihood of crime and violence. The lagged coefficient showed a higher value, indicating that the effects of institutional improvements on the degree of financial dollarization are stronger when considering the temporal dimension. Because the dollarization is persistent over time, institutional improvements take time to generate investor's portfolio reallocations. An improvement in the confidence in the rules of society in period $t-1$ causes a lower degree of financial dollarization in period $t$ in the studied economies. This effect is greater than the positive effect of institutions on dollarization.

Besides this, Honig (2009) show that even in a low-inflation environment financial dollarization results from a lack of faith in the domestic currency, which ultimately stems from the belief that the government will not follow policies that promote long-run currency stability. The results from Honig (2009) also show that government quality improvements reduce financial dollarization because better

\footnotetext{
${ }^{8}$ The variables considered to be exogenous were investment grade, rule of law, MVP and time dummies. The non-exogenous variables include lagged dollarized deposits, inflation, inflation volatility, inflation acceleration, interaction of debt-to-GDP and investment grade and debt-to-GDP.

${ }^{9}$ That is, $m v p=(\operatorname{var}(\pi)+\operatorname{cov}(\pi, s)) /(\operatorname{var}(\pi)+\operatorname{var}(s)+2 \operatorname{cov}(\pi, s))$.
} 
institutional arrangements induce the adoption of sound monetary and fiscal policies. Such an improvement would cause agents to believe that inflation will remain low in the future, dispensing with the need to protect their net wealth through financial dollarization (purchase of foreign currency-denominated assets).

Table 2

Determinants of Financial Dollarization - Two Step System GMM

\begin{tabular}{|c|c|c|}
\hline Variables & Coefficients & Robust Standard deviations \\
\hline Dollarized Deposits (t-1) & $1.095 * * *$ & 0.236 \\
\hline Inflation $(\mathrm{t})$ & $0.377 *$ & 0.195 \\
\hline Inflation (t-1) & - & - \\
\hline Inflation Volatility (t) & -0.324 & 1.715 \\
\hline Inflation Volatility (t-1) & -1.605 & 1.250 \\
\hline Inflation Acceleration $(\mathrm{t})$ & 0.026 & 0.102 \\
\hline Inflation Acceleration (t-1) & 0.013 & 0.063 \\
\hline $\operatorname{MVP}(\mathrm{t})$ & -0.060 & 1.250 \\
\hline $\operatorname{MVP}(\mathrm{t}-1)$ & $0.268 * *$ & 0.117 \\
\hline Rule of Law (t) & $1.610^{* *}$ & 0.733 \\
\hline Rule of Law (t-1) & $-1.730 * *$ & 0.762 \\
\hline Debt/PIB (t) & -0.152 & 0.356 \\
\hline Debt/PIB (t-1) & -0.056 & 0.198 \\
\hline Debt_grade $(t)$ & 0.305 & 0.384 \\
\hline Debt_grade (t-1) & 0.319 & 0.237 \\
\hline Speculative Grade & $-34.953 * *$ & 16.477 \\
\hline Financial Openness & -0.361 & 1.713 \\
\hline Initial per capita income & $4.534^{*}$ & 2.572 \\
\hline Foreign exchange regime dummy & -5.239 & 4.360 \\
\hline Country size & -0.228 & 0.571 \\
\hline Constant & -40.769 & 42.976 \\
\hline \multicolumn{3}{|l|}{ Test Specifications (p-value): } \\
\hline Sargan Test & 0.710 & \\
\hline 1st-order Serial Correlation & 0.038 & \\
\hline 2nd-order Serial Correlation & 0.529 & \\
\hline Number of countries: & 70 & \\
\hline Number of observations: & 456 & \\
\hline Number of instruments: & 31 & \\
\hline
\end{tabular}

Notes: We used the correction model proposed in Windmeijer (2005) to deal with the bias problem in small samples in two-step estimation of the standard deviations. No second-order serial correlation was detected in the residuals' first differences. The Sargan test does not reject the hypothesis that the restrictions identified above are valid. 
On the other hand, our estimations also show a positive relationship between institutional quality and financial dollarization. Our argument to explain this relationship is that, as economies develop their financial systems and more developed domestic securities markets become established, greater financial depth may, in addition to encouraging the purchase of domestic assets, cause economies to attract additional foreign currency funds from abroad ${ }^{10}$. Interestingly, the foregoing results for the rule of law variable show that the current and lagged coefficients have opposite signs. However, since the estimations were run with the initial per capita income variable, which captures countries' financial development level and whose positive coefficient was statistically significant, this may indicate that, controlling for an economy's financial depth level, the effect of institutional improvements on financial dollarization has an important temporal dimension ${ }^{11}$.

As concerns the speculative grade variable, as per Moody's ratings, estimations with restricted models indicate that economies with higher sovereign risks dollarize more than less risky ones. In addition, speculative economies with higher debt-to-GDP ratios offer greater incentives to dollarize. Table 2 shows these results. After the System GMM estimations in Table 2, we proceeded to eliminate variables that were not statistically significant, beginning with those with lower significance levels. We then built Table 3, below, which shows the results of estimations using 7 different specifications taking account of the different institutional variables discussed earlier ${ }^{12}$. Estimation of Models 1 and 2 in Table 2 used the following dependent variables: oneperiod-lagged dollarized deposit; current and one-period-lagged debt-to-GPD ratio; current and one-period-lagged interaction variable between debt-to-GDP ratio and speculative grade; speculative grade dummy; current and one-period-lagged rule of law; control variable measuring country size, represented by the natural log of real GDP; US interest rate (control variable), capturing changes in external liquidity conditions.

The results indicate highly persistent financial dollarization as reflected in the high statistical significance of the coefficient associated with lagged dollarization in all 7 models estimated. For Models 1 and 2, the control variables were not statistically significant, but their signs were as expected ${ }^{13}$. The estimation of Model 2 using the

\footnotetext{
${ }^{10}$ The initial per capita income variable present in Model 1 captures the economies' financial depth, and is also used in financial dollarization studies. The relationship between financial depth and per capita income was initially noted in a study by Goldsmith (1969) on the relationship between financial structure and economic development. Since then, several other authors have also observed this relationship, such as Levine \& Zervos (1996) and Backé et al. (2007). In their turn, authors like Yeyati (2006) and Bacha et al. (2009), in financial dollarization studies, use the initial per capita income as a proxy for the development of the local-currency denominated securities market. The authors' argument is that the more developed a country's local-currency denominated securities market, the greater its financial depth. And the greater this depth, the lower the bank holdings of foreign currency deposits (and assets) tend to be, given that the local-currency assets market is developed.

${ }^{11}$ Estimations were also run using other institutional variables similarly obtained from the World Bank's World Governance Indicators (WGI) database. They are: Control of corruption, regulatory quality, Government Effectiveness, Political Stability and Absence of Violence/Terrorism, and Voice and Accountability. Since these variables are mutually correlated, estimations were run using one at a time. The results show that these additional variables are not statistically significant and the results are therefore not reported. However, in the model estimation via System GMM found in Table 3 the institutional variables were included one at a time. The results indicate that only the variables rule of law, regulatory quality and Voice and Accountability were statistically significant.

${ }^{12}$ Not all statistically significant variables in Table 2 were included in Table 3 . The justification is that, as we eliminated non-significant variables one by one, other variables lost significance.

${ }^{13}$ Inclusion of the country-size variable is justified because larger countries have easier access to foreign loans in their own currencies than smaller countries. Larger countries provide better diversification opportunities for international investors in addition to having more developed domestic financial markets
} 
variable that captures changes in international liquidity conditions as a control, yielded better results than Model 1, which uses country size as a control variable. The coefficients for the lagged dependent variable and the interaction variable between debtto-GDP and speculative grade were higher, and the dummy for speculative grade became statistically significant, with the expected coefficient (Model 2).

The results of Model 2 show that the coefficients associated with the lagged interaction between debt and the speculative grade rating, speculative grade dummy variable and the lagged of rule of law variable was statistically significant at $5 \%$. The Arellano-Bond tests show that no second-order serial correlation of the residuals' first difference was detected, validating the GMM estimator's moment conditions. The Sargan test did not reject the hypothesis that the constraints identified above are valid, indicating that the explanatory variables' lagged values are valid as instruments. Neither domestic public debt (period $t$ and $t-1$ ) nor the interaction between debt and the speculative grade dummy variable in period $t$ were statistically significant. However, the lagged coefficient (period $t-1$ ) of the interaction between the debt-to-GDP ratio and the speculative grade dummy variable was significant at $5 \%$ with a coefficient of 0.27 , suggesting that the high indebtedness levels in countries that have not yet attained investment grade lead to more foreign currency deposits being held as a form of hedging. So, the impacts of this variable on the level of dollarization are long-term effects rather than short-term effects. Taking the Model 2 specification from Table 2, for a given debt-variable coefficient of 0.27 , in speculative economies, a 50 p.p. increase in debt-to-GDP ratios causes a long-term increase of 13.5 p.p. in dollarization. When debt-to-GDP ratios in these economies increases from a minimum of $11.3 \%$ to a maximum of $206.9 \%$, dollarization rises on average 224.73 p.p. in the long term ${ }^{14}$. In the case of Argentina, for example, which in the 1990s had an average debt-to-GDP of around $35.6 \%$, and average dollarization of $55.8 \%$, if debt-to-GDP were to increase by 50 p.p., reaching $53.4 \%$ from $35.6 \%$, dollarization would rise to almost $70 \%$.

An increase in debt-to-GDP takes some time to result in increased financial dollarization, possibly because investors' expectations concerning a government's failure to honor its payments take time to be realized. When the debt-to-GDP ratio rises, there is some time between the date of this increased and the date expected by the agents to a probable default of the government, which gives investors a time to seek protection mechanisms of their wealth, as is the case of financial dollarization. Thus, in speculative grade countries, as debt-to-GDP increases, investors will form expectations about the non-fulfillment of obligations of local governments. When the debt-to-GDP ratio reaches a critical level, investors no longer believe the government will honor its commitments. So, these agents sell domestic assets and buy dollarized assets, increasing the degree of financial dollarization of the economy. As for the institutional variable rule of law, its one-period-lagged coefficient was statistically significant, with the opposite sign than expected based on the institutional approach to dollarization. The positive relationship between rule of law and dollarization may be justified by the fact that as economies become more developed and their institutions improve, their financial

and being less prone to governmental errors (Eichengreen et al. 2003). The ability of larger countries to take loans abroad in their own currencies may reduce the pursuit and maintenance of foreign currency deposits. The US market interest rate was used to control for changes in international liquidity over time. Berkmen and Cavallo (2009) and Caballero and Krishnamurthy (2001) used this variable to control for international liquidity changes with the justification that, during economic crises, the inelastic supply of external funds may cause countries to fear dependence on changes in economic agents' portfolio choices.

14 The effect may be obtained in the following manner: $\left[\frac{(206.9-11.3) * 0.27}{1-0.765}\right]=224.73 p \cdot p$ 
depth tends to increase, expanding the range of assets available to residents, who are able to purchase both domestic and foreign assets, with increased foreign funds as a result of the greater financial depth.

In addition, Table 3 presents our results considering the institutional variables regulatory quality, government effectiveness, control of corruption, voice and accountability, and political stability. In models 3 to 7, these current variables showed negative coefficients, while their lagged coefficients were positive. Only lagged regulatory quality and current voice and accountability were statistically significant, with the former showing the opposite sign than expected. The voice and accountability variable captures the perceived degree to which a country's citizens participate in the choice of their government, as well as freedom of speech and association, and the presence of free media. Despite the low statistical significance of the variable voice and accountability, our results indicate that the greater the actors' political participation, the lower an economy's level of financial dollarization. This agrees with the empirical evidence found in Weymouth (2011), who argues that the presence of veto players improve investors' property rights as regards the value of the domestic currency. Using the concept of veto players originating from Tsebelis (2002), Weymouth argues that the presence of these actors in a society restricts opportunistic government policies, as it requires the agreement of multiple veto players representing different interests. Therefore, these actors restrict the policymakers' ability to adopt policies leading to depreciation of the domestic currency or to inflation, thereby improving the property rights of the holders of domestic assets. Consequently, financial dollarization is a result of investors lacking confidence in their property rights, which, in turn, occurs when veto players are few.

The regulatory quality variable measures the government's ability to provide sound policies and regulations that enable and promote development of the private sector. The results of the estimation of the model that incorporates this variable indicate that improved regulatory quality in an economy causes its dollarization level to increase. This positive effect is probably a result of the relationship between an economy's regulatory quality and its financial depth, as argued in the case of the rule of law variable. More developed domestic financial markets provide investors with a wider choice of assets. Since investors minimize risks, they will demand safer assets in environments with high price risks, encouraging foreign currency deposits.

To sum up, the results show that a high debt-to-GDP ratio is more responsible for increased dollarization in the studied economies than the risks associated with current inflation, such as the current inflation rate, current inflation acceleration, and current inflation volatility. The one-period-lagged debt-to-GDP variable was statistically significant, which indicates the presence of a lag between increasing debt-to-GDP ratios and investors' perceived possibility of sovereign default. High indebtedness levels generate inflation risks insofar as investors expect local governments not pay its debt. Perceived future inflation risks discourage the purchase of local-currency-denominated assets in favor of foreign currency-denominated assets, increasing financial dollarization.

Even with a clear decline in inflation rates, our results show that financial dollarization remains high in the four regions covered by this study. The debt level also remains high in regions such as America - Latin America in particular - Asia and Africa, where debts average over $60 \%$ of GDP. This debt level combined with speculative grade ratings from international agencies causes foreign currency deposits to remain high in those economies as a form of hedging against macroeconomic uncertainty. Our results indicate that persistent financial dollarization is due to the risk of future inflation caused by the risk of default, which had not been previously tested in the literature. 
Table 3

Two-Step System GMM Estimation Results - institutional variables

\begin{tabular}{|c|c|c|c|c|c|c|c|}
\hline Variables & (1) & (2) & (3) & (4) & (5) & (6) & (7) \\
\hline Dollarized Deposits (t-1) & $\begin{array}{c}0.612 * * \\
(0.230)\end{array}$ & $\begin{array}{c}0.765 * * \\
(0.195)\end{array}$ & $\begin{array}{l}0.765^{*} \\
(0.402)\end{array}$ & $\begin{array}{c}0.818 * * \\
(0.193)\end{array}$ & $\begin{array}{c}0.772 * * * \\
(0.180)\end{array}$ & $\begin{array}{c}0.664 * * \\
(0.250)\end{array}$ & $\begin{array}{c}0.648 * * * \\
(0.238)\end{array}$ \\
\hline debt/PIB (t) & $\begin{array}{c}0.106 \\
(0.158)\end{array}$ & $\begin{array}{c}0.074 \\
(0.170)\end{array}$ & $\begin{array}{c}0.194 \\
(0.293)\end{array}$ & $\begin{array}{c}0.101 \\
(0.211)\end{array}$ & $\begin{array}{l}-0.014 \\
(0.133)\end{array}$ & $\begin{array}{c}0.010 \\
(0.113)\end{array}$ & $\begin{array}{c}0.064 \\
(0.169)\end{array}$ \\
\hline $\mathrm{debt} / \mathrm{PIB}(\mathrm{t}-1)$ & $\begin{array}{c}-0.131 \\
(0.089)\end{array}$ & $\begin{array}{l}-0.142 \\
(0.089)\end{array}$ & $\begin{array}{l}-0.215 \\
(0.163)\end{array}$ & $\begin{array}{l}-0.154 \\
(0.097)\end{array}$ & $\begin{array}{l}-0.122 \\
(0.079)\end{array}$ & $\begin{array}{l}-0.103 * \\
(0.059)\end{array}$ & $\begin{array}{l}-0.124 * \\
(0.074)\end{array}$ \\
\hline debt_grade(t) & $\begin{array}{l}-0.175 \\
(0.177)\end{array}$ & $\begin{array}{l}-0.151 \\
(0.189)\end{array}$ & $\begin{array}{l}-0.281 \\
(0.282)\end{array}$ & $\begin{array}{l}-0.193 \\
(0.249)\end{array}$ & $\begin{array}{l}-0.077 \\
(0.137)\end{array}$ & $\begin{array}{l}-0.077 \\
(0.122)\end{array}$ & $\begin{array}{l}-0.056 \\
(0.168)\end{array}$ \\
\hline debt_grade(t-1) & $\begin{array}{l}0.265 * * \\
(0.112)\end{array}$ & $\begin{array}{c}0.272 * * \\
(0.129)\end{array}$ & $\begin{array}{c}0.346 * * \\
(0.177)\end{array}$ & $\begin{array}{l}0.339 * * \\
(0.145)\end{array}$ & $\begin{array}{c}0.301 * * * \\
(0.097)\end{array}$ & $\begin{array}{c}0.256 * * \\
(0.087)\end{array}$ & $\begin{array}{c}0.237 * * \\
(0.107)\end{array}$ \\
\hline Speculative Grade & $\begin{array}{c}8.538 \\
(8.727)\end{array}$ & $\begin{array}{l}5.928 * * \\
(9.728)\end{array}$ & $\begin{array}{c}3.063 \\
(15.195)\end{array}$ & $\begin{array}{l}-3.454 \\
(9.684)\end{array}$ & $\begin{array}{l}-6.862 \\
(6.513)\end{array}$ & $\begin{array}{c}-4.225 \\
(11.006)\end{array}$ & $\begin{array}{l}-5.771 \\
(6.808)\end{array}$ \\
\hline Rule of law (t) & $\begin{array}{l}-0.082 \\
(0.315)\end{array}$ & $\begin{array}{l}-0.059 \\
(0.228)\end{array}$ & - & - & - & - & - \\
\hline Rule of law (t-1) & $\begin{array}{l}0.329 * * \\
(0.152)\end{array}$ & $\begin{array}{l}0.309 * * \\
(0.125)\end{array}$ & - & - & - & - & - \\
\hline Control of corruption $(\mathrm{t})$ & - & $\begin{array}{l}- \\
-\end{array}$ & $\begin{array}{l}-0.033 \\
(0.303)\end{array}$ & - & - & - & - \\
\hline Control of corruption $(\mathrm{t}-1)$ & - & - & $\begin{array}{c}0.098 \\
(0.119)\end{array}$ & - & - & - & - \\
\hline Regulatory quality (t) & - & - & - & $\begin{array}{l}-0.132 \\
(0.260)\end{array}$ & - & - & - \\
\hline Regulatory quality (t-1) & - & - & - & $\begin{array}{l}0.195^{*} \\
(0.116)\end{array}$ & - & - & - \\
\hline Government Effectiveness (t) & - & - & - & - & $\begin{array}{l}-0.165 \\
(0.154)\end{array}$ & - & - \\
\hline Government Effectiveness ( $\mathrm{t}-1)$ & - & - & - & - & $\begin{array}{c}0.104 \\
(0.064)\end{array}$ & - & - \\
\hline $\begin{array}{c}\text { Political stability and Absence of } \\
\text { Violence/Terrorism (t) }\end{array}$ & - & - & - & - & - & $\begin{array}{l}-0.128 \\
(0.196)\end{array}$ & - \\
\hline $\begin{array}{c}\text { Political stability and Absence of } \\
\text { Violence/Terrorism (t-1) }\end{array}$ & - & - & - & - & - & $\begin{array}{c}0.098 \\
(0.072)\end{array}$ & - \\
\hline Voice and Accountability $(\mathrm{t})$ & - & - & - & - & - & - & $\begin{array}{l}-0.268 * \\
(0.156)\end{array}$ \\
\hline Voice and Accountability (t-1) & - & - & - & - & - & - & $\begin{array}{c}0.052 \\
(0.084)\end{array}$ \\
\hline Country size & $\begin{array}{l}-0.273 \\
(1.106)\end{array}$ & - & - & - & - & - & $\begin{array}{l}-0.282 \\
(0.595)\end{array}$ \\
\hline US interest rate & - & $\begin{array}{c}0.036 \\
(0.231)\end{array}$ & $\begin{array}{c}0.234 \\
(0.275)\end{array}$ & $\begin{array}{c}0.215 \\
(0.208)\end{array}$ & $\begin{array}{c}0.288 \\
(0.222)\end{array}$ & $\begin{array}{c}0.227 \\
(0.238)\end{array}$ & $\begin{array}{c}0.285 \\
(0.254)\end{array}$ \\
\hline Constant & $\begin{array}{c}-4.665 \\
(32.470)\end{array}$ & $\begin{array}{l}-10.968 \\
(15.396)\end{array}$ & $\begin{array}{c}-0.579 \\
(18.269)\end{array}$ & $\begin{array}{c}0.689 \\
(21.116)\end{array}$ & $\begin{array}{l}12.959 \\
(9.591)\end{array}$ & $\begin{array}{c}11.663 \\
(11.353)\end{array}$ & $\begin{array}{c}24.876 \\
(16.998)\end{array}$ \\
\hline \multicolumn{8}{|l|}{ Tests ( $p$-value) } \\
\hline Sargan Test & 0.527 & 0.477 & 0.264 & 0.313 & 0.698 & 0.624 & 0.694 \\
\hline 1st-order Serial Correlation & 0.000 & 0.003 & 0.080 & 0.034 & 0.024 & 0.054 & 0.007 \\
\hline 2nd-order Serial Correlation & 0.393 & 0.376 & 0.407 & 0.662 & 0.991 & 0.856 & 0.853 \\
\hline Number of countries: & 79 & 79 & 76 & 77 & 79 & 79 & 73 \\
\hline Number of observations: & 544 & 544 & 483 & 532 & 538 & 546 & 500 \\
\hline Number of instruments: & 15 & 15 & 18 & 18 & 18 & 18 & 16 \\
\hline
\end{tabular}

Notes: Robust standard deviations in parentheses. We used the correction model proposed in Windmeijer (2005) to deal with the bias problem in small samples in two-step estimation of the standard deviations. No second-order serial correlation was detected in the residuals' first differences. The Sargan test does not reject the hypothesis that the restrictions identified above are valid. Time dummies were used. 


\section{Final Remarks}

The purpose of this paper was to search for the determinants of financial dollarization and the causes of its persistence over time for a group of 79 economies at different development levels over the period 1991 - 2006. Many papers have previously studied the determinants of financial dollarization using variables that are relevant to their respective approaches. In addition to the dollarization determinants addressed in previous studies, we included additional variables to evaluate sovereign risk. System GMM dynamic panel estimations were performed with variables such as the inflation risks (captured in the MVP model) and the default risk. The estimates indicate that financial dollarization is better explained by the default risk variables, expressed by the debt-to-GDP ratio, and by the investment grade of the country than by variables that describe inflation risks.

However, unlike the inflation risks already tested in the literature, financial dollarization persists because of the future inflation risk arising from the risk of default. Even after the reduction of inflation and inflation volatility in the sample of 79 countries tested, inflation risk persists due to the risk of default in highly indebted economies. In this sense, the fact that some domestic and foreign investors perceive that there will be a default on the debt causes a flight to dollarized assets even before an actual default that may or may not occur, increasing the economy's financial dollarization level. In terms of policy implications, financial dollarization levels could decline in response to policies intended to reduce the risks associated with debt and investment that are present in over one-third of the studied economies. Implementing these policies is of great importance for these countries because financial dollarization has several negative consequences, including increased volatility and the loss of output during financial crises.

\section{APPENDIX}

Table A.1

Number of countries per region

\begin{tabular}{cc}
\hline Region and number of countries & Countries \\
\hline $\begin{array}{c}\text { Latin, North, South and Central America } \\
(22)\end{array}$ & $\begin{array}{c}\text { Argentina, Barbados, Belize, Bolivia, Chile, Colombia, } \\
\text { Costa Rica, Ecuador, El Salvador, Guatemala, Honduras, } \\
\text { Jamaica, Mexico, New Zealand, Nicaragua, Paraguay, Peru, } \\
\text { St. Vincent \& Grenadines, The Bahamas, Trinidad \& } \\
\text { Tobago, Uruguay, Venezuela }\end{array}$ \\
$\begin{array}{c}\text { Africa } \\
(4)\end{array}$ & $\begin{array}{c}\text { Egypt, Mauritius, Morocco, South Africa } \\
\text { Asia }\end{array}$ \\
& $\begin{array}{c}\text { Bangladesh, Bahrain, Cambodia, China Hong Kong, Fiji, } \\
\text { Georgia, Indonesia, Israel, Japan, Jordan, Kazakhstan, } \\
\text { Lebanon, Malaysia, Mongolia, North Korea, Oman, } \\
\text { Pakistan, Papua New Guinea, Philippines, Qatar, Saudi } \\
\text { Arabia, Sri Lanka, Thailand, Turkey, United Arab Emirates } \\
\text { Europe } \\
\text { Albania, Austria, Bulgaria, Croatia, Cyprus, Czech Republic, } \\
\text { Denmark, Estonia, Finland, Greece, Hungary, Iceland, Italy, } \\
\text { Latvia, Lithuania, Moldova, Norway, Poland, Slovak } \\
\text { Republic, Slovenia, Spain, Romania, Russia, Sweden, } \\
\text { Switzerland, The Netherlands, Ukraine, United Kingdom }\end{array}$ \\
\end{tabular}

Source: Prepared by the Authors. 
Table A.2

Basic descriptive statistics for the variables of interest

\begin{tabular}{|c|c|c|c|c|c|}
\hline Variables & Mean & Median & Maximum & Minimum & $\begin{array}{l}\text { Standard } \\
\text { Deviation }\end{array}$ \\
\hline Dollarization $(\%)$ & 26.4 & 21.5 & 97.3 & 0.06 & 23.8 \\
\hline Inflation (\% p.p.) & 9.0 & 4.5 & 176.1 & -3.9 & 14.5 \\
\hline Inflation acceleration (p.p.) & -1.41 & -0.3 & 58.06 & -136.9 & 9.0 \\
\hline Inflation volatility (p.p.) & 0.00 & 0.00 & 0.52 & 0.00 & 0.02 \\
\hline MVP (\%) & 26.2 & 24.3 & 100.0 & 0.00 & 21.1 \\
\hline $\begin{array}{l}\text { Per capita GDP } \\
\text { (US\$) }\end{array}$ & 8639.0 & 3667.8 & 43078.5 & 294.0 & 10409.2 \\
\hline Public debt to GDP & 54.1 & 47.3 & 304.5 & 0 & 36.8 \\
\hline Rule of law (0-100 scale) & 57.5 & 59.0 & 100.0 & 5.0 & 26.1 \\
\hline Control of corruption (0-100 scale) & 61.8 & 65.0 & 100.0 & 0 & 27.1 \\
\hline Regulatory Quality (0-100 scale) & 61.3 & 63.4 & 100.0 & 0 & 24.1 \\
\hline $\begin{array}{l}\text { Government Effectiveness } \\
(0-100 \text { scale })\end{array}$ & 60.8 & 62.6 & 100.0 & 0.0 & 24.9 \\
\hline $\begin{array}{c}\text { Political Stability and Absence of } \\
\text { Violence }(0-100 \text { scale })\end{array}$ & 52.5 & 53.4 & 100.0 & 1.92 & 27.2 \\
\hline $\begin{array}{l}\text { Voice and Accountability } \\
(0-100 \text { scale })\end{array}$ & 50.9 & 50.5 & 100.0 & 0.5 & 28.8 \\
\hline $\begin{array}{c}\text { Index of restrictions against } \\
\text { Dollarization }(0-5 \text { scale })\end{array}$ & 0.46 & 0.0 & 5.0 & 0.0 & 1.1 \\
\hline Capital account openness level & 0.79 & 1.18 & 2.54 & -1.80 & 1.48 \\
\hline
\end{tabular}

Source: Levy-Yeyati (2006); Honohan (2008); Bacha et al. (2007); AREAER (IMF); De Nicoló et al. (2003); IFS (IMF); World Economic Outlook, IMF; WGI, World Bank; Chinn \& Ito (2008); Moody's (2010). 
Table A.3

Selected Countries with decreasing inflation and increasing dollarization - $1992-2006$

\begin{tabular}{cccc}
\hline Country & Year & $\begin{array}{c}\text { Inflation drop } \\
\text { (p.p.) }\end{array}$ & $\begin{array}{c}\text { Dollarization increase } \\
\text { (p.p.) }\end{array}$ \\
\hline Albania & 1999 & 20.25 & 1.63 \\
Argentina & 1993 & 14.28 & 5.10 \\
Argentina & 1994 & 6.43 & 3.40 \\
Argentina & 1999 & 2.08 & 3.39 \\
Argentina & 2004 & 9.02 & 4.94 \\
Estonia & 1995 & 18.87 & 2.34 \\
Estonia & 1997 & 12.46 & 5.48 \\
Georgia & 1997 & 32.26 & 12.0 \\
Honduras & 1992 & 25.21 & 2.7 \\
Latvia & 1995 & 10.94 & 10.79 \\
Latvia & 1996 & 7.36 & 2.07 \\
Lithuania & 1995 & 32.49 & 1.80 \\
Mexico & 2000 & 7.09 & 3.08 \\
Mongolia & 1997 & 10.33 & 11.56 \\
Peru & 1993 & 24.94 & 3.95 \\
Poland & 1993 & 8.46 & 6.42 \\
Romania & 1999 & 13.29 & 5.76 \\
Romania & 2001 & 11.19 & 2.23 \\
Turkey & 1999 & 19.77 & 2.27 \\
\hline
\end{tabular}

Notes: The countries listed above (13 in all) had 1.6 p.p. or greater increases in dollarized deposits. The figure 1.6 corresponds to the 75th percentile of the variable that measures percentage point changes in dollarized deposits. Out of the 79 countries in our sample, 70 had (percentage point) increases in dollarized deposits together with a (percentage point) drop in inflation. Also, 50 out of the 79 countries had increased dollarized deposits by 1 p.p. or more despite a reduction in inflation of 1 p.p. or more.

Table A.4. Change in Dollarization, MVP and Price Dilution Risks from 1991-98 to 1999-06.

\begin{tabular}{|c|c|c|c|c|}
\hline Region & $\begin{array}{c}\text { Change in } \\
\text { Dollarized Deposits } \\
\text { (p.p.) }\end{array}$ & $\begin{array}{c}\text { Change in MVP } \\
\text { (p.p.) }\end{array}$ & $\begin{array}{c}\text { Change in Inflation } \\
\text { Volatility } \\
\text { (p.p.) }\end{array}$ & $\begin{array}{c}\text { Change in Inflation } \\
\text { Acceleration } \\
\text { (p.p.) }\end{array}$ \\
\hline $\begin{array}{c}\text { Latin, North, South } \\
\text { and Central } \\
\text { America } \\
(22)\end{array}$ & +3.10 & -1.38 & -0.000 & -2.70 \\
\hline $\begin{array}{c}\text { Africa } \\
(4)\end{array}$ & +3.40 & -2.44 & -0.001 & -1.52 \\
\hline $\begin{array}{c}\text { Asia } \\
(25)\end{array}$ & +5.10 & -2.76 & -0.004 & -3.53 \\
\hline $\begin{array}{c}\text { Europe } \\
(28)\end{array}$ & +3.30 & -3.60 & -0.003 & -2.39 \\
\hline
\end{tabular}

Source: Prepared by the authors based on data from Honohan (2008), Levy-Yeyati (2010) and IMF. 
Table A.5. Correlations between rule of law and other institutional variables

\begin{tabular}{cccccc}
\hline Year & $\begin{array}{c}\text { Voice \& } \\
\text { Accountability }\end{array}$ & $\begin{array}{c}\text { Government } \\
\text { Effectiveness }\end{array}$ & $\begin{array}{c}\text { Political Stability \& } \\
\text { Absence of } \\
\text { Violence/Terrorism }\end{array}$ & $\begin{array}{c}\text { Regulatory } \\
\text { Quality }\end{array}$ & $\begin{array}{c}\text { Control of } \\
\text { Corruption }\end{array}$ \\
\hline 1996 & 0.77 & 0.86 & 0.78 & 0.79 & 0.88 \\
1998 & 0.80 & 0.93 & 0.83 & 0.88 & 0.94 \\
2000 & 0.83 & 0.94 & 0.87 & 0.89 & 0.94 \\
2002 & 0.81 & 0.94 & 0.85 & 0.90 & 0.93 \\
2003 & 0.81 & 0.87 & 0.85 & 0.90 & 0.93 \\
2004 & 0.83 & 0.91 & 0.83 & 0.90 & 0.95 \\
2005 & 0.84 & 0.92 & 0.84 & 0.90 & 0.93 \\
2006 & 0.81 & 0.90 & 0.83 & 0.89 & 0.94 \\
\hline Source: Prepared by the authors based on data from the World Bank's Worldwide Governance Indicators (World Bank).
\end{tabular}

\section{References}

Acemoglu, D., Johnson, S., Robinson, J. A, 2001. The colonial origins of comparative development: An empirical investigation. American Economic Review 91

Anderson, T.W., Hsiao, C, 1981. Estimation of Dynamic Models with Error Components. Journal of American Statistical Association 76, 598-606.

Arellano, M., Bond, S. 1991. Some Tests of Specification for Panel Data: Monte Carlo Evidence and an Application to Employment Equations. Review of Economic Studies 58, 277-97.

Arellano, M., Bover, O., 1995. Another look at the instrumental variable estimation of error-components models. Journal of Econometrics 68, 29-51.

Arida, P., Bacha, E., Lara-Resende, A., 2005. Credit, interest, and jurisdictional uncertainty: conjectures on the case of Brazil. In F. Giavazzi, I. Goldfajn and S. Herrera (eds.), Inflation Targeting, Debt, and the Brazilian Experience, 1999 to 2003, 265-93. MIT Press.

Arteta, C., 2002. Exchange rate regimes and financial dollarization: does flexibility reduce bank currency mismatches? International Finance Discussion Papers 738.

Arteta, C., 2003. Are financially dollarized countries more prone to costly crises? International Finance Discussion Papers 763. Board of Governors of the Federal Reserve System.

Berkmen, P., Cavallo, E. A., 2007. Exchange Rate Policy and Liability Dollarization: What Do the Data Reveal About Causality? IMF Working Paper 07/33.

Bacha, E., Holland, M., Gonçalves, F., 2007. Is Brazil Different? Risk, Dollarization, and Interest Rates in Emerging Markest. IMF Working Papers 07/294, International Monetary Fund.

Bacha, E., Holland, M., Gonçalves, F., 2009. A Panel-Data Analysis of Interest Rates and Dollarization in Brazil. Revista Brasileira de Economia 63, 341-360. 
Backé P., Égert B., Walko Z., 2007. Credit Growth in Central and Eastern Europe Revisited. Focus on European Integration 2, 69-77.

Baltagi, B. H., 2005. Econometric analysis of panel data. New York.

Blundell, R, Bond, S., 1998. Initial conditions and moment restrictions in dynamic panel data models. Journal of Econometrics 87, 115-143.

Branson, W. H., Henderson, D. W., 1985. The specification and influence of asset markets. Chapter 15 in Handbook of International Economics 2, 749-805.

Broda, C., Levy-Yeyati, E., 2003. Dollarization and the lender of last resort, in E. Levy Yeyati and F. Sturzenegger, editors. Dollarization, MIT Press, Cambridge, MA.

Broda, C., Levy-Yeyati, E., 2006. Endogeneous Deposit Dollarization. Journal of Credit, Money and Banking 38, 963-88.

Caballero, R, Krishnamurthy, A., 2001. Vertical analysis of crises and intervention: fear of floating and ex-ante problems. NBER Working Paper 8428.

Cagan, P., 1956. The monetary dynamics of hyperinflation. In: Friedman, M., editor. Studies in the quantity theory of money. Chicago, University of Chicago Press.

Calvo, Guillermo A., Rodrigues, C. A., 1977. A Model of Exchange Rate Determination under Currency Substitution and Rational Expectations. Journal of Political Economy, 85, 617-625.

Calvo, G. A., Vegh, C. A., 1992. Currency Substitution in Developing Countries: An Introduction. International Monetary Fund Working Paper 92/40.

Chinn, M. D., Ito, H., 2008. A New Measure of Financial Openness. Journal of Comparative Policy Analysis: Research and Practice 10, 309-322.

De La Torre, A., Schmukler, S. 2004. Coping with risks through mismatches: domestic and international financial contracts for emerging economies, International Finance, 7. 349-390.

De Nicoló, G., Batholomew, P., Zaman, J., Zephirin, M., 2003. Bank Consolidation, Conglomeration and Internationalization: Trends and Implications for Financial Risk. IMF Working Paper 03/158.

De Nicoló, G., Honohan, P., Ize, A., 2005. Dollarization of bank deposits: causes and consequences. Journal of Banking and Finance 29, 1697-1727.

Égert B., Backé P., Zumer T., 2007. Private-Sector Credit in Central and Eastern Europe: New (Over) Shooting Stars? Comparative Economic Studies 49, 201231.

Friedman, M., 1963. Inflation: Causes and Consequences. Asia Publishing House, New York.

Girton, L., Roper, D., 1981. Theory and Implications of Currency Substitution. Journal of Money, Credit, and Banking 13,12-30.

Goldsmith, R. W., 1969. Financial Structure and Development. New Haven, Yale University Press.

Gonçalves, F., Holland, M., Spacov, A., 2007. Can jurisdictional uncertainty and capital controls explain the high level of real interest rates in Brazil? Evidence from panel data. Revista Brasileira de Economia 61, 49-75.

Guidotti, P. E., Rodriguez, C. A., 1992. Dollarization in Latin America - Gresham law in reverse. International Monetary Fund Staff Papers 39, 518-544.

Hawkins, J., Masson, P., 2003. Economic aspects of regional currency areas and the use of foreign currencies. BIS papers number 17.

Hawkins, J., 2003. Central bank balance sheets and fiscal operations. BIS Papers 20.

Honig, A., 2009. Dollarization, Exchange Rate Regimes and Government Quality. Journal of International Money and Finance 28, 198-214.

Honohan, P., 2008. The Retreat of Deposit Dollarization, International Finance 11. 
Ilzetzki, E.O, Reinhart, C.M., Rogoff, K., 2009. Exchange Rate Arrangements into the 21st Century: Will the Anchor Currency Hold? Harvard University, Cambridge and University of Maryland, College Park.

International Monetary Fund., 2009. World Economic Outlook (WEO) Database.

Ize, A., Levy-Yeyati, E., 1998. Dollarization of Financial Intermediation: Causes and Policy Implications. IMF Working Paper 98/28.

Ize, A., Levy-Yeyati, E., 2003. Financial Dollarization. Journal of International Economics 59, 323-347.

Ize, A., Kiguel, M., Levy-Yeayti, E., 2006. Managing Systemic liquidity risk in a financially dollarized economy, in A. Armas, A. Ize e E. Levy-Yeyati, editors, Financial Dollarization: The Policy Agenda. Palmgrave, London.

Jaimovich, D., Panizza, U., 2010. Public debt around the world: a new data set of central government debt. Applied Economics Letters 17, 19-24.

Kokenyne, A., Ley, J., Veyrune, R., 2010. Dedollarization. IMF Working Paper 10/188.

Levine, R., Zervos, S., 1996. Stock Market Development and Long-Run Growth. World Bank Economic Reveiw 10, 323-39.

Levy-Yeyati, E., Sturzenegger, F., 2005. Classifying exchange rate regimes: Deeds vs. words. European Economic Review 49, 1603-1635.

Levy-Yeyati, E., 2006. Financial Dollarization: evaluating the consequences. Economic Policy, January. 61-118.

Levy-Yeyati, E., 2010. Dataset: Deposit Dollarization and Dollarization restrictions.

Liviatan, N., 1981. Monetary Expansion and Real Exchange Rate Dynamics. Journal of Political Economy 89, 1218-1227.

Miles, M. A., 1978. Currency Substitution, Flexible Exchange Rates, and Monetary Independence. American Economic Review 68, 428-36.

Moody's., 2010. Moody's Investors Service.

North, D. C., Weingast, B. R.,1989. Constitutions and commitment: The evolution of institutional governing public choice in seventeenth-century England. Journal of Economic History 49, 803-832.

Ortiz, Guillermo. 1983. Currency Substitution in Mexico: The Dollarization Problem. Journal of Money, Credit and Banking 15, 174-85.

Reinhart, C., Rogoff, K., Savastano, M., 2003. Addicted to Dollars. National Bureau of Economic Research Working Paper 10015.

Rennhack, R., Nozaki, M., 2006. Financial Dollarization in Latin America. IMF Working Paper 06/7.

Romer, D., 2006. Advanced Macroeconomics. McGraw-Hill/Irwin; Third edition.

Salles, F., 2007. Liquidity, jurisdictional uncertainty, and high interest rates in Brazil. London School of Economics.

Sargent, T. J., 1982. The End of Four Big Inflations. In Robert E. Hall, editor. Inflation: Causes and Effects, 41-98. Chicago: University of Chicago Press.

Savastano, M.A., 1992. The pattern of currency substitution in Latin America: an overview. Revista de Analisis Economico 71, 29-72.

Thomas, L. 1985. Portfolio Theory and Currency Substitution. Journal of Money, Credit and Banking 17, 347-357.

Tsebelis, G., 2002. Veto players: How political institutions work. Princeton.

Weymouth, S., 2011. Political Institutions and Property Rights: Veto Players and Foreign Exchange Commitments in 127 Countries. Comparative Political Studies, 44, 211-240.

Windmeijer, F., 2005., A Finite Sample Correction for the Variance of Linear Efficient Two-step GMM Estimators. Journal of Econometrics 126, 25-51. 